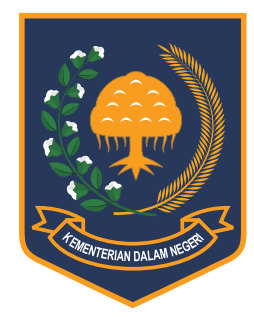

Jurnal Bina Praja 8 (2) (2016): 331-340

Jurnal Bina Praja

e-ISSN: 2503-3360 | p-ISSN: 2085-4323

Accreditation Number

735/AU2/P2MI-LIPI/04/2016

http://jurnal.kemendagri.go.id/index.php/jbp/index

\title{
POVERTY REDUCTION \\ for Extremely Poor Households of Malang City BY THE IMPLEMENTATION OF PROGRAM KELUARGA HARAPAN
}

\author{
Wimmy Haliim ${ }^{1, *}$ \\ ${ }^{1}$ Department of Political Sciences, Universitas Brawijaya \\ Jl. Veteran - Malang Kota - Jawa Timur - Indonesia
}

Received: 7 February 2016; Accepted: 12 October 2016; Published online: 30 November 2016

DOI: $10.21787 / \mathrm{jbp} .08 .2016 .331-340$

\begin{abstract}
This research is based on the low access of poor families to basic education and health care in Malang City that have an impact on social welfare and poverty problem. To overcome these problems, Ministry of Social Affairs of the Republic of Indonesia through Malang City Government and Social Department of Malang City implements Program Keluarga Harapan (PKH) in the form of conditional cash transfers to the Extremely Poor Households (RTSM). The result showed that the implementation of PKH has been implemented properly and according to the procedure and the number of RTSM recipients of $\mathrm{PKH}$ from year to year has decreased. Nevertheless, this program implementation does not significantly impact the number of poor people in the city of Malang in general.
\end{abstract}

Keywords: program implementation, poverty, Program Keluarga Harapan.

\section{INTRODUCTION}

Poverty is a phenomenon and a social problem that must be continually assessed. Poverty basically is closely related to fulfilling the needs of health and education. To minimize the social welfare problems, especially poverty which always continues to grow from day to day, the Indonesian government through the Ministry of Social Affairs issued a program called Program Keluarga Harapan (PKH). The program tries to develop a system of social protection for the poor in Indonesia. The program is implemented by the Social Department which is one of the government agencies engaged in the social field. To succeed this program, it is assisted by experts of PKH and World Bank consultants (Pedoman Umum PKH, 2008: 62).

The concept of the welfare state is triggered by Kranenburg. Kranenburg, quoted by Esping and Andersen (1990: 18-19), argues that the State should be actively seeking the welfare, act fairly which can be felt by the entire community and balanced, not for particular social class, but all the people without exception.
In Indonesia, the concept of welfare refers to the concept of social welfare development, namely a series of activities that are planned, institutionalized, and intended to improve the standard and quality of human life (Pradikta, 2013: 2). Suharto (2005) said that in other countries, a term widely used is the 'welfare' which conceptually cover all processes and activities of the welfare of the citizens and explain the system of social services and social protection schemes for disadvantaged/poor households.

In the third world countries, such as in Indonesia, the poverty happens to focus on the economic backwardness of the country as the root of the problem (Hardiman and Midgley, in Suharto, 2005: 131). The country's population is poor, according to Kuncoro (1997: 131), because it relies on the agricultural sector subsystem, traditional production methods, which are often accompanied by apathy towards the environment.

The phenomenon of poverty in many third world countries, especially after World War II, has brought up the theory of development in its approach to poverty with two different perspectives, namely the theory of modernization and dependency

\footnotetext{
* Corresponding Author

Phone : +62341575755

Email : halious90@gmail.com
} 
theory. Generally, modernization theory sees how the impact of modernization in a developing country, and how big the impact of modernization creates poverty. Then the dependency theory is an approach which saying that the underdevelopment experienced by developing countries that have been intensively receiving assistance from developed countries led to dissatisfaction with the assumptions to put forward by the theory of modernization (Gujarati, 2003).

In Indonesia, especially in Malang, $\mathrm{PKH}$ is the implementation of Presidential Decree (Perpres) No 15 Year 2010 on accelerating poverty reduction and Malang Mayor Decree (Keputusan Walikota) No 188.45/159/35.73.112/2014 concerning Executive Team Operations of PKH. In addition, the researchers chose the unfortunate city, because this city has the highest human development index (IPM) in Eastern Java. That is obtaining a score of 80.5 (BPS, 2015). It can be assumed that if the human development index is high, it means that the government can reduce the poverty to the maximum. Therefore, it is very interesting when this research is able to show the effectiveness of this program in reducing poverty.

Implementation of the program is an activity or efforts undertaken to implement all plans and policies that have been formulated and determined to come with everything needed (Syukur, 1987: 402). Implementation of the program in principle is that a policy of the background of the program can achieve its objectives. No more and no less.

Korten in Anderson (1997: 12) said that a program will be successfully implemented if there is conformity of the three elements of the implementation of the program, namely: (1) compatibility between the program beneficiaries, (2) compatibility between programs with the implementing organization, (3) compatibility between user groups with the implementing organization.

Then, the implementation of the program in the context of public policy consists of several steps: (Tachjan, 2006: 35) (a) Designing the program and details of the task and the formulation of clear objectives, (b) Implementing (application) the program by empowering the structure and personnel, funds as well as other sources. (c) Building a system scheduling, monitoring, and means of appropriate supervision and evaluation as the results of implementation.

We can see some of the criteria in the assessment of whether a policy implementation process has gone well, notice to several factors, including: (1) Does the organization prepared the technical implementation? (2) Do the program implementers already understand the plans, objectives, and policy objectives? (3) Are the actors have been set and ready to accept the responsibility of implementing the program? (4) Is the coordination between the implementers has been done well? (5) Do the obligation and the right, have been given and understood, and executed well by implementing policies? (6) Does the assessment criteria for the success of the existing program, obviously, and appropriately implemented by the program implementers? (Esmara, 2010: 43).

$\mathrm{PKH}$ has given a hope for people in the city of Malang in order to increase the degree and improve the quality of human resources in the family or household through improving their access to health care and education. PKH implementation is also expected to contribute reducing the number of poor households in Malang, which from year to year, whereas in 2013-2015 the number of poor people reached 40.9 thousand or $4.85 \%$ of the total population of the city of Malang as many as 820,243 people. (BPS Kota Malang, 2013)

According to the Directorate of Social Security in Program Keluarga Harapan Companion Book (Pedoman Umum PKH, 2013: 1), Program Keluarga Harapan (PKH) is a program of social protection through cash transfers to poor/very poor households, as long as they fulfill the obligations. $\mathrm{PKH}$ at an early stage has been implemented in Indonesia since 2007 and is expected to run continuously at least until 2015 , and for the local region that is just starting $\mathrm{PKH}, \mathrm{PKH}$ implemented for at least six years since the implementation of the $\mathrm{PKH}$ in the local region.

PKH objectives and benefits are following: (1) Improving the socio-economic status by providing additional revenue of RTSM income effect. (2) Maximizing the nutritional status and health of children, pregnant mothers, postpartum mothers, infants, and, children aged 5-7 years who have not yet entered elementary school. (3) Maximizing the quality and access to health and education. (4) Increasing the level of education of children so as to reduce the number of child workers. And (5) Accelerating the achievement of the MDGs.

Based on the explanation, it makes the premise of researchers to conduct research on how the implementation of PKH in Social Department of Malang City affected RTSM. It is expected that these studies could show how the real form of implementation of the PKH for RTSM in Malang City. Therefore, the researchers determined the title of the study is: "Poverty Reduction for Extremely Poor Households of Malang City by the Implementation of Program Keluarga Harapan."

\section{MeThoD}

Based on the research objectives, this study included in this type of descriptive study using a qualitative approach. The focus of the research is the 
implementation of the PKH in Social Department of Malang City, where the latter will be able to conclude how the implementation is detailed as follows:

1. Implementation of the Program Keluarga Harapan (PKH) for extremely poor households (RTSM).

2. Supporting and inhibiting factors of the implementation of the Program Keluarga Harapan for extremely poor households (RTSM).

Then, research location is Malang City and the site of research is the Social Department of Malang City. The data source of this research is the primary data source in qualitative research including words, actions, and additional data such as documents and others (Miles, Huberman, and Saldana, 2014: 12). And then, the source of the data used in this research interviews regarding the implementation of PKH in Social Department as well as documents related to the implementation of $\mathrm{PKH}$.

\section{RESULT AND DISCUSSION}

\section{A. The Implementation of Program Keluarga Harapan for Extremely Poor Households}

\section{1) The Preparation Stage of the Program Keluarga Harapan Implementation}

a. The Preparation of Program Keluarga Harapan Implementation

Program Keluarga Harapan (PKH) is one part of control programs and poverty reduction that was declared as a national program by the Ministry of Social Affairs. PKH implemented in almost all provinces in Indonesia. One of the participating provinces to implement the program is the province of East Java. As the location of the study, the researchers chose Malang as study site of the PKH implementation. PKH in Malang began in 2013 with as many as 4,834 participants PKH recipient RTSM. $\mathrm{PKH}$ aid component consists of support to health and education for very poor households. This assistance will indirectly help the poor to escape from the poverty trap (Kusuma, 2013: 214).

$\mathrm{PKH}$ is the government's policy on poverty reduction to the poor in accordance with the criteria of $\mathrm{PKH}$ recipient. It is expected that with $\mathrm{PKH}$, the extremely poor households (RTSM) will have better access to take advantage of basic social services in health, education, food and nutrition, eliminating social inequality, powerlessness and social isolation that has been attached to the poor.

PKH as a program requires the implementation so that its impact can be felt by the community (Susanto, 2010: 80). In the implementation, the stage of preparation is necessary so that the program is running regularly and can achieve its goals. Both of the goals, planning, until the actors involved in the implementation.

The results of this study on the implementation of the PKH for RTSM in Social Department of Malang City has shown that in the implementation there are mechanisms that must be executed so that the program can run well. The mechanism of early implementation of $\mathrm{PKH}$ is at the preparation stage of preparing a program until the program is ready to be implemented. At the stage of preparation of the implementation, $\mathrm{PKH}$ is planning the implementation of programs ranging from the central to the local implementation.

Mechanisms subsequent form of the willingness and commitment of the government both provincial and City/ Regency for implementing $\mathrm{PKH}$ in the region, the willingness of data on aspects related to the target $\mathrm{PKH}$ such as data mortality rate of mothers and infants, data on the number RTSM, and the support facilities of the local government for PKH implementation (post office, health facilities, educational facilities).

Once the mechanism is ready, the preparation for the future is the establishment of the secretariat of UPPKH as program implementation unit located at the central level to the district, recruitment, training and equipping of PKH Assistants by Receiving Education and Training from Social Ministry and Central Office of UPPKH. PKH Assistants is the eyes and ears of UPPKH with $\mathrm{PKH}$ aid recipients in the field.

According to Syukur (1987: 402), the implementation of the program requires tools that are needed, who is carrying out, where a program is started and how it should be implemented, a process of a series of follow-up activities after the program or policy set consisting of decision-making, strategic and operational measures or policies into reality in order to achieve the objectives of the program that has been set previously.

In the implementation of $\mathrm{PKH}$, especially at this preparatory stage, 
as we have discussed earlier there are mechanisms such as the regional elections, the establishment of the secretariat, and the recruitment of assistants. The next step in the implementation of PKH in Social Department Malang City, based on the findings that there are various kinds of planning the preparation of the what, who, where, when, and how the implementation of the program will be implemented. On the results of research, there are other mechanisms such as determining who will be the participants of PKH in Malang City, and it is necessary to check directly with the people in the field according to the data obtained from the BPS central office.

The next stage after the selection of participants completed is the initial preparation for the socialization of how the program will run later, after the assistant do the initial mechanism of preparing a program such as how is the initial payment of this aid, the formation of groups of women participants in $\mathrm{PKH}$, verification of the participants' commitment to health facilities and educational facilities, and updating the participants to avoid mismatches against state aid of $\mathrm{PKH}$ participants.

Based on this research, the mechanism of preparation for implementation of $\mathrm{PKH}$ had been planned and organized as precise as possible so that the implementation of the program runs properly. In addition, the results of research can be seen that there are many parties involved in the implementation of the $\mathrm{PKH}$, especially at the stage of preparation. The program objectives and the institutional check are done regularly from the center to the regions as a support to the preparatory phase of implementation of this program.

b. The Implementation Strategy of Program Keluarga Harapan

Program Keluarga Harapan (PKH) is one of the programs in the Government's strategy to reduce poverty, especially for extremely poor households. In $\mathrm{PKH}$, aid is on the RTSM targets that have pregnant women, infants and school-age children who are not in school or have not completed primary education 9 (nine) years. Mubyarto (2002) stated that poverty occurs due to the low quality of education, factors other than the quantity that cannot meet demand. In the PKH the main component is the assistance is in the field of education and health. With the PKH it is expected to reduce poverty in the community and break the chains of poverty by improving the quality of human resources (Pedoman Umum PKH, 2008: 12).

In the implementation of the program, there should be a strategy that is applied in order to achieve the objectives that have been set previously. Preparation of implementers and measures to be implemented can be one of the strategies that will help facilitate the realization of the program objectives. According to the United Nation in Zauhar (1993: 2) in order to achieve the success of a program, it would include making efforts in the field of management including supply, financing, and others to implement the program.

Based on the results of this study, the strategies applied in the implementation of the PKH covers initial planning prior to the implementation of the strategy, human resources, and a commitment to implement a program in accordance with the standards and procedures that have been established. The strategy adopted by the Social Department in the form of support for the location of the secretariat UPPKH in Malang adjacent to Social Department as UPPKH coach. Also in terms of organization, Social Services put competent human resources in the field of social empowerment as part of the organization of UPPKH.

Another strategy implemented was the training and the training of human assistant who will accompany the participants who will go to the field. In the implementation of PKH especially in Malang, a different strategy implemented by Social Department is an assistant placement to help to solve problems which may come from their origin. It is a strategy to facilitate closeness and $\mathrm{PKH}$ information in any activity that can support the success of the program.

Based on the results of interviews with informants also proved that their commitment and attitude of an assistant who willing and trying to be close to the various parties involved in the community as participants of $\mathrm{PKH}$, the officers in the health facilities as well as teachers in educational facilities will also expedite the implementation of this program. It can be concluded that the coordination and readiness of the various parties in the implementation of $\mathrm{PKH}$ in Malang City can be the right strategy in supporting the success of this program. 
c. The Socialization of Program Keluarga Harapan Implementation

Before a program is implemented, socialization needs for parties who are involved in the implementation. With socialization, the expected parties involved in the future implementation of the program will knowabout what, who, when, where, and how the program was implemented. This socialization is also needed for implementers and beneficiaries of the program to be able to implement the program smoothly without any obstacles with adequate information about the program.

According to Charles 0 . Jones in Usman (2002: 28), that one of the pillars of activity in operating the program is the interpretation which the executive should be able to run the program in accordance with the technical guidance and implementation guidelines for the objectives expected to be achieved. So, that implementers and participants can interpret the program hence the need for socialization. In the implementation of $\mathrm{PKH}$, socialization is designed so that there is a process of communication, information flow, and learning on the executors in the central to local level, the media, NGOs, academics and the public, as well as aid recipients, especially in areas that carry PKH program (Yasa, 2008: 88).

Based on the results of this study of the implementation of $\mathrm{PKH}$ in Social Department Malang City, so far the program has worked well with their good socialization process. PKH conducted socialization to all parties involved from the central to the local level so that all parties involved could get information related to the program (Habibullah, 2011: 105). In addition, people who do not become $\mathrm{PKH}$ participants were also given information about the program. It is intended that the general public can be an agent of social control for the participants to carry out its obligations as $\mathrm{PKH}$ participants.

There are three components presented in the community as well as the parties who are involved in $\mathrm{PKH}$. The three components are socialization, educating the public, and advocacy. Socialization is to convey information, education aims to change the mindset and behavior of people to escape poverty, and advocacy aimed at building awareness, concern, and commitment.
As expressed by Supriatna in Suryono (2010: 243) that one of the things that must be done in the program to alleviate and reducing poverty is the process of forming the coalition network and communication between the bureaucracy with local NGOs, independent of the traditional organizational unit, and so forth. Thus, in the implementation of PKH can be concluded that socialization is one part of the measures to expedite implementation and poverty reduction programs.

2) The Execution Stage of Program Keluarga Harapan

a. The Main Target of Program Keluarga Harapan

Execution is an important part of an implementation program by the government. From the above results, PKH has specific targets from the beginning since the program was created. Regarding the targeting of participants, $\mathrm{PKH}$ implementation in Malang also has to follow the criteria set by the center. Generally, the targets of Program Keluarga Harapan are as follows: a) RTSM in which there are pregnant/postpartum, b) RTSM in which there are toddlers (0-6 years old), and c) RTSM in which there are children under the age of 18 years who have not completed primary education.

With more details of the main target in the implementation of $\mathrm{PKH}$, the execution of the program can be more optimally assessed. Because according to Syukur (1987: 389), one element in the process of implementation of a program is the targeted community groups and benefit from the program of change and improvement. The use of PKH aid is to improve the quality of education and health of RTSM. Therefore, the awardee of grants is a mother or a mature woman who takes care of the household. It is hoped that it will help to have a more effective impact because its receiver is the one who takes care of children in the household. The recipient may be replaced by grandmother, aunt, or sister if the mother is not there. Exceptions to this provision can be made in certain circumstances, for example, if the house has no adult women, it can be replaced by the head of the family. Beneficiaries of these names will be listed on the card of PKH which is conclusive evidence when taking payment. 
A target related with the program who will receive funds from the aid. At Program Keluarga Harapan, recipient of aid funds is the mother or an adult woman who took care of the household. Apart from that, based on BPS data PKH program also involves assistant and local community leaders to avoid mistakes and jealousy. Because building a good policy, not merely to develop the country, but also to ensure that the country can still be alive and to give meaning together. (Nugroho, 2014: 770).

However, in order for $\mathrm{PKH}$ can run more optimally and have a real impact on the RTSM, Suryono (2010: 243), states that the government needs to do the steps below, include: a) The existence of an initiative or decision to meet public needs made in local tiers, b) Maximizing the potential of poor people in terms of supervision and guidance of assets in order to meet their needs, c) the existence of the social learning process in which there are collaborative interaction between the bureaucracy and the community, ranging from planning to project evaluation, d) the importance of institutional culture, and e) the process of forming the coalition network and communication between the bureaucracy with local NGOs, traditional organizational units independently, etc.

b. The Aid Nominal Amount of Program Keluarga Harapan

Social assistance program such as $\mathrm{PKH}$ is prone to the presence of social tension that makes people feel jealous of each beneficiary. Therefore, it is needed for officers who will survey the state of the target program immediately to minimize these things from happening. Governments are required to find a solution to all the problems that occur in the field. By doing so, indirectly Malang city government will formulate a superior public policy to be implemented in the city. However, public policy is upstream of each of the life of a community called state, where the interaction of each actor to find an answer that is mutually beneficial to build the nation's future (Nugroho, 2014: 90).

In the research, the amount of aid for PKH participants from 2013 to 2015 suffered some changes. In 2013 to 2015 the first stage there is no help for RTSM who have children who participated in similar high school education. This is because at that time considered to be a high school education does not include as a category for children's education assistance for RTSM. In 2015, phase II has been held for RTSM assistance who have children in high school or high school equivalent. The criteria are divided on aid assistance in the field of health and aid in the field of education. Providing support for education and health, especially the very poor households with the requirements of pregnant/postpartum and/or children under 6 years old (Utomo, 2013: 32).

These days, PKH is directed and supervised by the Department of Social Malang and its implementation by UPPKH much clearer and focused in stages than in previous years. Implementation of the program in principle is that a policy underlying the program that can achieve its objectives. But because this PKH aid in the form of the material (money), poor social services through UPPKH State must remain vigilant in the face of conflict in society caused by the amount of the aid.

A program implementation is believed to be successful if there is a match between the three elements of the implementation of the following program, which is (Anderson, 1997: 12): (1) compatibility between schemes and the beneficiaries of the program, (2) the suitability of the program with the implementing organizations, and (3) the benefits received by a group of users can be adjusted with the activities undertaken by the implementing organizations, namely the correspondence between the prerequisites that have been decided by the implementing organizations in order to obtain the results of the program which can be implemented by the target group of the program.

c. The Implementation Target of Program Keluarga Harapan

The implementation target of $\mathrm{PKH}$ is associated with efforts to reduce poverty and as much as possible to break the chain of poverty by the empowerment of poor communities through awareness of the importance of health and education. Thus, with them conscious of the importance of health and education, the quality of their human resources will increase. It also makes the understanding in society in order to change their behavior that is unfavorable to the improvement of their welfare. In short, the target is to help the poor to break out of poverty and so that people are aware of the 
importance of health and education for the quality of human resources of RTSM could be increased. To achieve these targets, $\mathrm{PKH}$ has indicators to monitor whether the target has been implemented or not.

Grindle (1980: 11) explained that the content of the program must describe the following aspects: (1) interest of affected, (2) type of benefit, (3) extent of change envisioned, (4) site of decision making, (5) program implementers, and (6) committed resources.

On the side of the extremely poor households, the biggest problem of them not being able to continue with their education needs are a lack of resources and access to work for a living. So as for their health problems. Then from the service side, which is the fundamental reason of the low access to extremely poor households to access to health and education is the lack of availability of access to education and health that can be reached by very poor households. The service charge is impressed costly and as well as the distance from the residence and the location of the remote service of RTSM have become a separate obstacle for providers of health care and education.

In the perspective of 'social policy', $\mathrm{PKH}$ has given hope to the increase in the social security system for extremely poor households in Malang City. Family programs expectation in Malang has obliged the extremely poor households to check their health, provide immunizations and monitoring of child development, including providing access to education for children, it will give a change to the behavior of the very poor households, especially in understanding the importance of health and education.

\section{3) The Evaluation Stage of Program Keluarga Harapan}

In the field, before making an evaluation process, both the Department of Social and UPPKH monitoring during $\mathrm{PKH}$ program running in the community. In conducting the monitoring, UPPKH has a standard reference from the center of what should be evaluated and monitored. In monitoring, there are inputs and outputs. In the evaluation of outcomes, there must be impacts. This is done so that the results of monitoring and evaluation in accordance with the objectives of the program. This reference is in the form of indicators and monitoring the execution of the evaluation (Usman, 2014: 3).

Esmara (2010: 43) explains to see whether the process of implementation of the program has been running well there are criteria that need to be considered, some of which is:

1. Has the technical implementation unit been set up?

2. Are the policy implementers have understood the plans, goals, and objectives of the policy?

3. Are the main actors have been set and ready to accept responsibility for the implementation of these policies?

4. Is the coordination of implementation has been done well?

5. Does the rights and obligations, powers and responsibilities have been assigned and understood and implemented properly by implementing policies?

6. Are the assessment criteria of successful implementation of existing policies, clear, and well implemented?

Evaluation of the implementation of $\mathrm{PKH}$ in Malang includes result and outcomes indicators. The indicator is the result of $\mathrm{PKH}$, the indicator describes the percentage of health care coverage for pregnant/postpartum and infant participants $\mathrm{PKH}$ by district/city, and community health centers; The percentage of coverage of education for children of participants of PKH in elementary, junior high, and high school.

Next is the PKH impact indicators, which is: declining levels of poverty in the household of $\mathrm{PKH}$ participants after 2 to 4 years ofimplementation of the program; the decrease of malnutrition for children under five after 2 to 4 years of implementation of the program; increasing consumption of energy foods and protein after two years of implementation of the program; increase in the average length of school children of RTSM after 2-4 years of program implementation; increasing school enrollment rate of children from RTSM after 2-4 years of program implementation. At least UPPKH Malang explained that 60 percent of program benefits by groups of people with the lowest incomes.

Facts on the field, UPPKH Malang had done some evaluation process as disclosed experts. Dunn (2004: 612) said that the evaluation of policy implementation at the time of the evaluation process is usually called. Evaluation of evaluation policy also called the consequences (output) or evaluation of policies and impact/effect (outcome) policy, or as a summative evaluation.

This evaluation is useful for recertification participants, whether they are still worthy of assistance or economic circumstances should have been able to pass from PKH membership. This evaluation in UPPKH is being done by the Centre in collaboration with the BPS, the officer will come to $\mathrm{PKH}$ participants and conduct surveys and interviews about economic conditions after 
three years as a PKH participant, then the status of participant education, living conditions, and so forth. The thing that has been done by UPPKH Malang through PKH assistant in the community is to monitor and go directly to $\mathrm{PKH}$ participants to ensure these indicators in monitoring and evaluation process have been met.

\section{B. The Supporting and Inhibiting Factors of Program Keluarga Harapan for Extremely Poor Household}

\section{1) The Supporting Factors}

Good structure is absolutely required by an institution to implement its program to the fullest. According to Winarno (2002: 126-151), Bureaucratic Structure is an important element as a whole became executor of a program and policy. Due to the structure of each bureaucrat in bureaucracy had separated each of the duties and functions. Hence, the work they do will be more clear and focused.

The bureaucratic structure is certainly able to realize the meaning of a program which has been devised to be applied to the maximum. In the approach to strategic model expressed by Nugroho (2014: 549), Structure Bureaucracy can better define the meaning of strategic planning, can make decisions and important actions that shape and guide how to be an organization, what the organization, and why organizations do such a thing.

Nugroho (2014: 534) also revealed that the institutional model approach, that government is the legitimate institution to make public policy. Policy formulation institutional model simply means that the task of creating public policy is the task of the government. Therefore, in order to make public policy run up to, the bureaucratic structure is needed so that the government can function for making public policy.

Next, the supporting factors of the implementation of PKH for RTSM are adequate facilities, sharing Fund of the City Government, and additional sharing funds received from the Provincial Government. Winarno (2002: 126-151) also said that the resources possessed become very important to the success of an implementation of a program.

Important sources that support the implementation of programs and policies are such as sufficient employees who have good skills to execute their duties, powers, and facilities to support the delivery of public services (Purwanto, 2013). Adequate facilities, sharing Fund of the City Government, and additional sharing funds received from the Provincial Government are "sources" which owned by the Department of Social Malang to maximize the implementation of the PKH for RTSM.

Next is a good coordination between the Assistant of PKH with education and health facilities. Winarno (2002: 126-151) revealed that one of the factors supporting a program implementation is communication. The transmission of intention in the communication process, consistency, and clarity are three important things that are discussed in the process of policy communications. Transmission is an official aware that a decision has been made and an order has been issued for its implementation. Clarity, not only guide policy implementation must be received by implementing policies and programs, but also should be clear communication (Setiyaningati, 2012: 14). Consistency, commands of execution must be consistent and clear.

Public awareness to follow the procedure properly is the final factor that can support the implementation of the PKH to run optimally. When the implementers and community well-being and support a program and then most likely policy implementation and policy program will run well and fit for purpose. The field, public awareness, especially housewives' beneficiaries by itself will hold gatherings/meetings once every month with the Assistant of PKH. The Society is a forum for counselors to update the data. Often in the society, mothers tell how the latest social conditions of households and RTSM available in the environment.

\section{2) The Inhibiting Factors}

On the implementation of a program or policy, there must be some problems which become an obstacle to its implementation. It also happened in the implementation of $\mathrm{PKH}$ in Malang City. If examined more deeply, the problems that arise in the field more to the sociological factors, psychological and communication (Simanjuntak, 2010: 90). Provocation of society is a sociological barrier because it is more to the stirring up of the environment of the handful of people who feel disadvantaged because they are not eligible for assistance from the PKH. Then, people who are not present at the meeting for updating the data are the psychological barriers of society. And the lack of coordination between UPPKH the Regional Coordinators (Korwil) is an inhibitor of the communication factor.

Problems of provocation often occur on the field when the poor have to deal with money. Receiving parties will be more reticent and those who did not receive would prefer to do a variety of ways to also receive assistance, such as provocation among citizens. But when talking about the problems faced by a program, the government is still looking for a way out.

The second is a psychological problem that caused by some of the people who received aid 
but did not attend the meeting to update the data and information. It can be classified as a cultural problem that occurs in poor communities. That is laziness, according to Baswir, as quoted by Suryono (2010: 236), to mention one kind of poverty and at the same factors that cause poverty, one of which, poverty is caused by cultural factors such as indiscipline or lazy.

Then the last problem is the lack of coordination between UPPKH the Regional Coordinators (Korwil). The problem is the problem of communication between agencies. According to Sunggono (1994: 149-153), the policy implementation can be inhibited because of the problems of information and communication, especially between agencies. The stakeholders in the implementation of programs and policies that are directly involved have important information. If this information is not available, for example, due to a communication breakdown, the implementation will also be inhibited.

\section{ConClusion}

Based on the formulation of the problem, along with discussion of the results of research that has been done by researchers in the previous chapter, the researchers can draw conclusions that each stage in the preparation, implementation, and evaluation of the PKH Program has been done well, because of the supporting factors like human resources, facilities and infrastructures, and coordination among all parties involved.

In this research recommendation, the researchers suggested, first, to the assistant of PKH to use the BPS latest data as a reference, in addition to the coordination in the field as in the RT/RW, village authorities as the circumference of the smallest need to be intensified to get accurate data. Second, is giving understanding to the person who graduating from the $\mathrm{PKH}$ program in order not to find ways to remain a participant of PKH. Third, the government should be able to advise participants to take part in social empowerment programs such as PNPM, KUBE (Business Group) contained in the Social Department, and others. And the last, to face the problem of lack of communication between PKH assistants in one region to another region, there is a need for the media usage to also receive another opinion although not meet directly. The media can be formally through the official website of $\mathrm{PKH}$, community blogs, social media such as Facebook, and others.

\section{ACKNOWLEDGEMENT}

Authors would like to express her utmost gratitude to the Social Service of Malang city, which has provided the data for the purposes of this research. The authors also thank the co-PKH, employees and The Head of The Social Services that are willing to give their precious time to be interviewed for this research. Then the authors also express her appreciation to fellow political science lecturer of FISIP-UB which has been taking the time to discuss the improvement of the research.

\section{REFERENCES}

Anderson, J. E. (1997). Public Policy-Making (3rd ed.). New York: Holt Rinchart Winston.

Badan Pusat Statistik. (2015). Data Kota Malang 2015. Retrieved September 17, 2016, from Ipm. bps.go.id/data/kabkot/metode/baru3573

Badan Pusat Statistik. (2011). Malang dalam Angka 2011. Malang: Badan Pusat Statistik Kota Malang.

Dunn, W. N. (2004). Public Policy: An Introduction. New Jersey: Pearson Education.

Esmara, H. (2010). Perencanaan dan Pembangunan di Indonesia. Jakarta: Gramedia Pustaka Utama.

Esping-Andersen, G. (1990). The Three Worlds of Welfare Capitalism. Oxford: Oxford University Press.

Grindle, M. S. (1980). Politics and Policy Implementation in the Third World. Princeton, N.J.: Princeton University Press.

Gujarati, D. N. (2003). Basic Econometrics (4th ed.). New York: John Willey \& Sons.

Habibullah. (2011). Peran Pendamping pada Program Keluarga Harapan Kabupaten Karawang. Jurnal Informasi (Kajian Permasalahan Sosial Dan Usaha Kesejahteraan Sosial), 16(2), 101-116.

Kementerian Sosial. (2008). Pedoman Umum PKH. Jakarta: Direktorat Jaminan Sosial-UPPKH Pusat.

Kementerian Sosial. (2013). Buku Pendamping PKH. Jakarta: Direktorat Jaminan Sosial-UPPKH Pusat.

Mubyarto. (2003). Penanggulangan Kemiskinan di Indonesia. Retrieved from http://jer.mubyarto. org/edisi_14/artikel_4.htm

Nugroho, R. (2014). Public Policy. Jakarta: Elex Media Komputindo.

Pradikta, E. P. (2013). Implementasi Program Keluarga Harapan (PKH) Bidang Kesehatan di Desa Pulo Kecamatan Jombang Kabupaten Jombang. Publika, 1(3).

Purwanto, S. A., Sumartono, \& Makmur, M. (2013). Implementasi Kebijakan Program Keluarga Harapan (PKH) dalam Memutus Rantai Kemiskinan (Kajian di Kecamatan Mojosari Kabupaten Mojokerto). Wacana, 16(2), 79-96. Retrieved from http://wacana.ub.ac.id/index. php/wacana/article/view/246

Setiyaningati, T. I., \& Triana, R. W. (2012). Dampak Pelaksanaan Program Keluarga Harapan 
(PKH) di Bidang Kesehatan terhadap Upaya Meningkatkan Kesehatan Ibu dan Anak di Kecamatan Puri Kabupaten Mojokerto. Jurnal Kebijakan Dan Manajemen Publik, 4(4).

Simanjuntak, M., Puspitawati, H., \& Djamaludin, M. (2010). Karakteristik Demografi, Sosial, dan Ekonomi Keluarga Penerima Program Keluarga Harapan (PKH). Jurnal Ilmu Keluarga Dan Konsumen IPB, 3(2), 101-113.

Suharto. (2005). Analisis Kebijakan Publik: Panduan Praktis Mengkaji Masalah dan Kebijakan Sosial. Bandung: Alfabeta.

Sunggono, B. (1994). Hukum dan Kebijaksanan Publik. Jakarta: Sinar Grafika.

Suryono, A. (2010). Dimensi-dimensi Prima Teori Pembangunan. Malang: Universitas Brawijaya Press.

Susanto, D. (2010). Strategi Peningkatan Kapasitas Modal Sosial dan Kualitas Sumberdaya Manusia Pendamping Pengembangan Masyarakat. Jurnal Komunikasi Pembangunan IPB, 8(1), 77-89. Retrieved from http://jesl.journal. ipb.ac.id/index.php/jurnalkmp/article/ view/5696

Syukur, A. (1987). Study Implementasi Latar Belakang Konsep Pendekatan dan Relevansinya dalam Pembangunan. Makassar: Persadi.

Tachjan, H. (2006). Implementasi Kebijakan Publik. Bandung: Truen RTH.

Usman, C. (2014). Efektivitas Program Keluarga Harapan (PKH) dalam Rangka Penanggulangan
Kemiskinan (Suatu Studi di Kecamatan Kota Utara Kota Gorontalo). Jurnal Administrasi Publik Unsrat, 2(1), 1-13. Retrieved from http://ejournal.unsrat.ac.id/index.php/JAP/ article/view/4503

Usman, N. (2002). Konteks Implementasi Berbasis Kurikulum. Jakarta: Raja Grafindo Persada.

Utomo, D., Hakim, A., \& Ribawanto, H. (1996). Pelaksanaan Program Keluarga Harapan dalam Meningkatkan Kualitas Hidup Rumah Tangga Miskin (Studi pada Unit Pelaksana Program Keluarga Harapan). Jurnal Administrasi Publik $U B, 2(1), 29-34$.

Widyakusuma, N. (2013). Peran Pendamping dalam Program Pendampingan dan Perawatan Sosial Lanjut Usia di Lingkungan Keluarga (Home Care): Studi tentang Pendamping di Yayasan Pitrah Sejahtera, Kelurahan Cilincing, Kecamatan Cilincing Jakarta Utara. Informasi, 18(2), 211-224. Retrieved from http://ejournal.kemsos.go.id/index.php/ Sosioinforma/article/view/59

Winarno, B. (2002). Teori dan Proses Kebijakan Publik. Yogyakarta: Media Pressindo.

Yasa, I. G. W. M. (2008). Penanggulangan Kemiskinan Berbasis Partisipasi Masyarakat di Provinsi Bali. INPUT Jurnal Ekonomi Dan Sosial Unud, 1(2), 86-91. Retrieved from http://ojs.unud. ac.id/index.php/input/article/view/3187

Zauhar, S. (1993). Administrasi Program dan Proyek Pembangunan. Malang: IKIP Malang. 